\title{
STUDI PROSES INDIRECT TEACHING DALAM PEMBENTUKAN KARAKTER DIRI KEIMANAN DAN SIKAP SOSIAL (Kajian Komparatif-Implementatif Pembelajaran Kurikulum 2013 Perspektif Sosiologi Pendidikan Di SMA Muhammadiyah I dan SMA BOPKRI I Yogyakarta)
}

\author{
Nurrohmah, Subiyantoro, M. Agung Rokhimawan \\ Email: rokhimawan78@gmail.com
}

\begin{abstract}
Abstrak
Kajian dalam penelitian ini berusaha mengungkap mengenai bagaimana peluang yang ada dalam kurikulum 2013 dalam membentuk konsep diri religius peserta didik, sebagai kontribusi pendidikan di sekolah dalam pembentukan karakter peserta didik. Tujuan penelitian ini untuk mengetahui tentang kemunculan proses pendidikan karakter keimanan siswa sebagai implikasi adanya KI-1 dan pendidikan karakter sosial sebagai implikasi KI-2 dalam Indirect Teaching di kelas dalam penerapan kurikulum 2013, serta mengetahui strategi penguatannya di SMA Muhammadiyah 1 dan SMA BOPKRI 1 Yogyakarta. Pembentukan karakter diri keimanan dalam Indirect Teaching pada kedua sekolah ini, sama-sama belum tampak muncul dalam konteks pembelajaran di kelas. Strategi penguatan implementasi kurikulum 2013 dalam membangun karakter Iman dan Sosial pada ke dua sekolah ini, dapat terlihat melalui kegiatan di sekolah yang bersifat kultural dengan titik tekan dan karakteristik yang berbeda. Karakter Iman terbangun melalui kegiatan yang terkait dengan kegiatan keagamaan, sedangkan karakter sosial seperti kedisiplinan, patriotisme, kekeluargaan, dan keramahan juga terbangun dalam kegiatan kultural di sekolah.
\end{abstract}

Kata Kunci: Indirect Teaching, karakter keimanan dan sosial, kurikulum 2013

\begin{abstract}
Studies in this study tried to unravel about how the opportunities that exist in the curriculum in 2013 in the form of self-concept of religious students, as the contribution of schooling in shaping the character of students. The purpose of this research is to know about the appearance of the character education faith of students as the implications of the KI-1 education and social character as implications KI-2 in Indirect Teaching in class in the implementation of the curriculum in 2013, as well as knowing the strategy gains in SMA Muhammadiyah 1 and SMA BOPKRI 1 Yogyakarta , Self-belief in the character formation Indirect Teaching at both schools, both not seem to have emerged in the context of learning in the classroom. Strategies to strengthen the implementation of the curriculum in 2013 in establishing the character of the Faith and Social on to these two schools, can be seen through school activities that are culturally with pressure point and different characteristics. Faith woke character through activities related to religious activities, while the social
\end{abstract}


character such as discipline, patriotism, family, and hospitality also awakened in cultural activities in schools.

Keywords: Indirect Teaching, faith and social character, curriculum 2013

\section{A. Pendahuluan}

Pada tahun 2013, pemerintah menggulirkan perubahan kurikulum. Tema pengembangan kurikulum 2013 adalah dapat mengahasilkan insan Indonesia yang produktif, kreatif, inovatif, dan afektif melalui penguatan sikap (tahu mengapa), keterampilan (tahu bagaimana), dan pengetahuan (tahu apa) yang terintegrasi. ${ }^{1}$ Tertuang dalam pengantar Menteri Pendidikan dan Kebudayaan bahwa titik tekan pengembangan kurikulum 2013 adalah penyempurnaan pola pikir, penguatan tata kelola kurikulum, pendalaman dan perluasan materi, penguatan proses pembelajaran, dan penyesuaian beban belajar, agar dapat menjamin kesesuain antara apa yang diinginkan dengan apa yang dihasilkan.

Kurikulum 2013 dikembangkan dengan berbasis pada kompetensi, sangat diperlukan sebagai instrumen untuk mengarahkan peserta didik menjadi manusia berkualitas yang mampu dan proaktif menjawab tantangan zaman yang selalu berubah, dan manusia terdidik yang beriman dan bertakwa kepada Tuhan Yang Maha Esa, berakhlak mulia, sehat, berilmu, cakap, kreatif, mandiri dan warga negara yang demoratis dan bertanggung jawab. Hal tersebut secara eksplisit telah disebutkan di dalam Undang-Undang Republik Indonesia Nomor 20 tahun 2003 tentang Sistem Pendidikan Nasional sebagai tujuan pendidikan nasional.

Rasional pengembangan kurikulum ini disebutkan bahwa, dilakukan karena adanya berbagai tantangan yang dihadapi, baik internal maupun eksternal. Tantangan internal terkait dengan tuntutan pendidikan yang mengacu pada 8 (delapan) Standar Nasional Pendidikan (SNP). Tantangan

\footnotetext{
${ }^{1}$ Rafik, Konsep dan Implementasi Kurikulum 2013,Bahan Workshop PLPG-LPTK-FITK-UIN Sunan Kalijaga, Yogyakarta: FITK-UIN, 2013, h.2.
} 
eksternal berkaitan dengan tantangan masa depan, kompetensi yang diperlukan di masa depan, persepsi masyarakat, perkembangan pengetahuan pedagogi dan berbagai fenomena negatif yang mengemuka. Fenomena negatif ini sangat dirasakan karena rendahnya karakter out put peserta didik, yang ditandai sering munculnya tawuran antar pelajar, genggeng pelajar yang marak di setiap kota dan bergerak "di bawah tanah", bahkan pada kasus-kasus tertentu secara ekstrim sampai pada tingkat membunuh.

Banyak kritik dilontarkan terhadap kebijakan pendidikan pada tataran implementasi dalam memahami peserta didik karena telah berubah menjadi "pemasungan" daya kreatif individu. ${ }^{2}$ Beliau menyimpulkan bahwa belajar kognitif cenderung tidak peduli pada perasaan dan lingkungan sosial. Menurut beliau belajar kognitif tidak dapat dilakukan pada suasana yang tidak mendukung afeksi. Selama ini sekolah-sekolah lebih mementingkan kemampuan kognisi, daya nalar dan keterampilan menjawab soal-soal ujian. Pendidikan nilai yang berkaitan dengan karakter, kepribadian terutama untuk dimensi afektif termarjinalkan.

Kajian dalam penelitian ini berusaha mengungkap mengenai bagaimana peluang yang ada dalam kurikulum2013 dalam membentuk konsep diri religius peserta didik, sebagai kontribusi pendidikan sekolah atau madrasah dalam pembentukan karakter peserta didik. Interaksi yang bermakna dalam kurikulum 2013 ini, berpeluang melalui pencapaian Kompetensi Inti 1 (Keimanan/spiritual) dan Kompetensi Inti 2 (Sosial) yang harus dicapai melalui semua mata pelajaran.

Dalam kurikulum 2013, peluang membangun karakter peserta didik ini diberi ruang yang sangat luas pada pencapaian Kompetensi Inti 1 tentang pencapaian kompetensi spiritual, dan Kompetensi Inti 2 tentang

\footnotetext{
2 Abdul Munir Mulkhan, Nalar Spiritual: Solusi Problem Filosofis Pendidikan Islam, Yogyakarta: Tiara Wacana, 2002, h.17.
} 
Jurnal Pendidikan Agama Islam pencapaian kompetensi sosial. Sebagaimana kita ketahui bahwa pencapaian kedua kompetensi tersebut terintegrasi dalam pembelajaran pada semua mata pelajaran. Di sinilah diperlukan komitmen dan kompetensi guru itu sendiri. Jadi dalam hal ini kompetensi spiritualitas guru dipertaruhkan, karena hal tersebut akan sangat mewarnai dalam interaksinya dengan peserta didik di kelas maupun di luar kelas.

Pembinaan peserta didik melalui saluran budaya yang dibangun melalui interaksi dalam semua mata pelajaran antara peserta didik dengan guru itulah diharapkan akan terbentuk konsep diri religius siswa, yang pada akhirnya telah dan akan terus menjadi kontribusi sekolah bagi pembentukan karakter peserta didik. Sejalan dengan perspektif sosiologi pendidikan, menurut Cooley, konsep diri (self-consept) seseorang berkembang melalui interaksinya dengan orang lain. ${ }^{3}$

Masalah yang diangkat dalam penelitian ini. Pertama Bagaimana proses pembentukan karakter diri keimanan dan karakter diri sosial peserta didik dalam indirect teaching pada pembelajaran di kelas dalam implementasi kurikulum 2013 di SMA Muhammadiyah I dan di SMA BOPKRI I Yogyakarta?. Kedua Bagaimana strategi penguatan implementasi kurikulum 2013 dalam membangun karakter diri keimanan (KI-1) dan karakter diri sosial (KI-2), agar pendidikan karakter mencapai keberhasilan?.

Penelitian ini mengambil lokasi pada sekolah swasta yang bernaung di bawah yayasan yang berbeda, bahkan berbeda latar belakang keagamaannya, yakni antara yayasan Islam di SMA Muhammadiyah I dan di bawah yayasan Kristen di SMA BOPKRI I Yogyakarta. Latar belakang dipilihnya setting penelitian di sekolah tersebut, dengan pertimbangan bahwa sekolah di bawah yayasan agama tentunya lebih perhatian dalam

\footnotetext{
3 Kamanto Sunarto,Pengantar Sosiologi, edisi ketiga. Jakarta: Lembaga Penerbit Fakultas
} Ekonomi, Universitas Indonesia, 2004, h.23. 
membangun keberagamaan peserta didiknya. Kancah dan setting penelitian ini juga menarik, karena SMA Muhammadiyah I dan SMA BOPKRI I merupakan sekolah di bawah yayasan agama yang berbeda, dan kedua sekolah tersebut merupakan sekolah swasta terdepan dan tertua di kalangan Islam maupun Kristen, serta sama-sama ditunjuk sebagai pilot proyek pelaksanaan kurikulum 2013. Penelitian ini berupaya mengetahui bagaimana kemunculan proses pendidikan karakter Keimanan siswa sebagai implikasi adanya Kompetensi Inti 1 (K.I.1) dan pendidikan karakter sosial sebagai implikasi Kompetensi Inti 2 (K.I.2) dalam Indirect Teaching di kelas dalam penerapan kurikulum 2013. Disamping itu penelitian ini juga bertujuan mengetahui strategi penguatan dalam pembentukan karakter keimaanan dan sosial peserta didik, dengan mencermati aktivitas antara guru dengan peserta didik di kelas dalam pengelolaan pembelajaran K.I.1 dan K.I.2.

\section{B. Metode Penelitian}

Penelitian ini adalah penelitian naturalistik dengan pendekatan kualitatif. Sampel sumber data diperoleh secara pusposive sampling, uji keabsahan data dengan triangulasi. Menurut Conny R Semiawan (2007: 180), penelitian kualitatif cenderung berorientasi fenomenologis, artinya ia mengamati gejalanya dengan memfokuskan penerapannya dari segi pandangan yang diteliti. 4 Peneliti menggali data berdasarkan apa yang diucapkan, dirasakan dan dilakukan oleh partisipan, yakni bersifat "perspektif emic". Penerapan penelitian ini bahwa peneliti mengobservasi proses pembelajaran di kelas pada beberapa proses kegiatan beberapa mata pelajaran. Observasi dilakukan terutama pengamatan dan analisis tentang kemunculan dimensi keimanan (spiritualitas) dan dimensi sosial

\footnotetext{
${ }^{4}$ Conny R Semiawan,Catatan Kecil Tentang Penelitian dan Pengembangan Ilmu Pengetahuan, Jakarta: Prenada, 2007, 180
} 
Jurnal Pendidikan Agama Islam

dalam proses indirect teaching yang dilakukan para guru dalam implementasi kurikulum 2013.

Subyek penelitian kualitatif tidak menggunakan populasi tetapi “social situation" yang terdiri dari tiga elemen yakni tempat (place), pelaku (actors), dan aktivitas (activity) yang berinteraksi secara sinergis. ${ }^{5}$ Tempat penelitian ini adalah SMA Muhammadiyah I dan SMA BOPKRI I Yogyakarta, tentang aktivitas pendidikan keimanan dan sosial siswa di kelas oleh para aktornya terutama guru mata pelajaran. Subjek penelitian, sebagai aktor pendidikan, meliputi para guru yang mengajar dalam penerapan kurikulum 2013. Disamping itu juga meneliti para siswa sebagai subyek pendidikan. Data diperoleh dengan dokumentasi, observasi partisipan, dan wawancara mendalam (indepth interview).

\section{Analisa Data}

Di dalam penelitian ini dilakukan observasi proses kerja madrasah dalam pola pembinaan siswa dalam pendidikan religius dan sosial, dari sisi proses pengumpulan data, maka dilakukan observasi berperan serta (participation observation) dan dari segi instrumentasi yang digunakan maka observasi terstruktur dan observasi tidak terstruktur (Sugiyana, 2006: 204). Pengujian keabsahan data akan meliputi uji credibility (validitas internal); transferability (validitas eksternal); dependability (reliabilitas); dan confirmability (obyektivitas). Analisis data bersifat induktif-kualitatif, adapun proses analisis dengan model Miles and Huberman. Dalam penelitian kualitatif ini, analisis data lebih difokuskan selama proses di lapangan bersamaan dengan pengumpulan data. Analisis data yang ditawarkan meliputi proses data reduction, data display, dan conclution drawing/veryvication.

\footnotetext{
5Sugiyono, Metode Penelitian Kualitatif, Bandung: PT. Rosda Karya, 2006,h. 297-298.
} 
Skema Penelitian: Proses Pendidikan Karakter Keimanan dan Sosial

\section{Siswa di kelas}

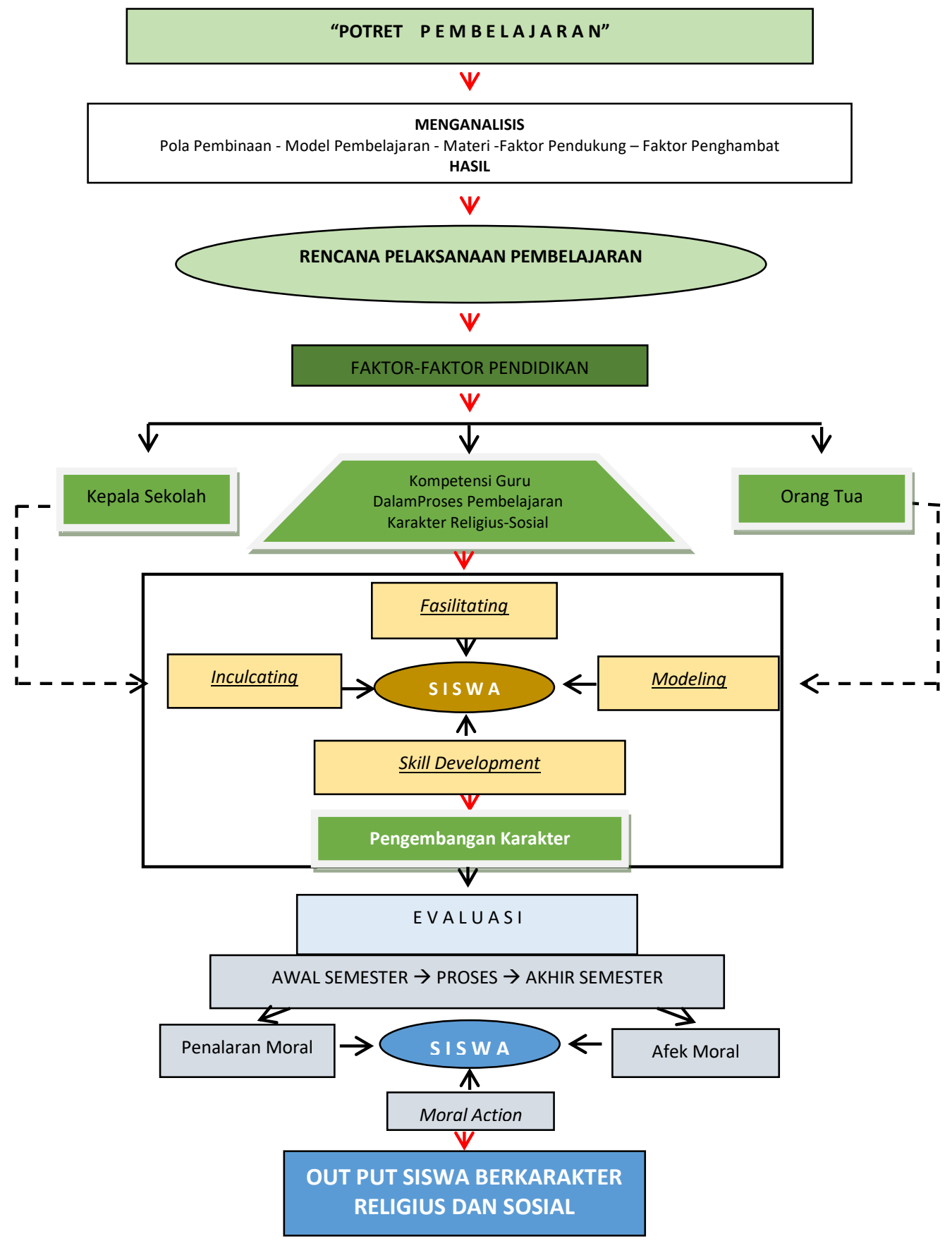




\section{Pembahasan}

\section{a. Pembentukan Karakter Siswa}

Secara etimologis, kata karakter (Inggris: character) berasal dari bahasa Yunani (Greek), yaitu charassein yang berarti "to engrave". Kata "to engrave" bisa diterjemahkan mengukir, melukis, memahatkan, atau menggoreskan. Dalam Kamus Bahasa Indonesia kata "karakter" diartikan dengan tabiat, sifat-sifat kejiwaan, akhlak atau budi pekerti yang membedakan seseorang dengan yang lain, dan watak. Secara terminologis, makna karakter dikemukakan oleh Thomas Lickona. Menurutnya karakter adalah "A reliable inner diposition to respon to situations in a morally good way". Selajutnya Lickona menambahkan "character so considerd has three interelated parts: moral knowing, moral feeling, and moral behavior". Menurut Lickona karakter mulia (good character) meliputi pengetahuan tentang kebaikan, lalu menimbulkan komitmen (niat) terhadap kebaikan, dan akhirnya benar-benar melakukan kebaikan. Dengan kata lain, karakter mengacu kepada serangkaian pemikiran (cognitives), perasaan (affectives), dan perilaku (behaviors) yang sudah menjadi kebiasaan (habits). ${ }^{6}$

Untuk melengkapi pengertian tentang karakter ini akan dikemukakan juga pengertian akhlak, moral, dan etika. Kata akhlak berasal dari bahasa Arab "al-akhlaq" yang merupakan bentuk jamak dari kata "alkhuluq" yang berarti budi pekerti, perangai, tingkah laku, atau tabiat. Sedangkan secara terminologis akhlak berarti keadaan gerak jiwa yang mendorong ke arah melakukan perbuatan dengan tidak menghajatkan pikiran. Inilah pendapat yang dikemukakan oleh Ibnu Maskawaih. Sedangkan Al-Ghazali mendefinisikan akhlak sebagai suatu sifat yang tetap pada jiwa yang dari padanya timbul perbuatan-perbuatan dengan mudah,

\footnotetext{
6Darmiyati Zuchdi, Pendidikan Karakter Konsep Dasar dan Implementasi di Perguruan Tinggi.
} Yogyakarta: UNY Press, 2012, h.15-16. 
Jurnal Pendidikan Agama Islam

dengan tidak membutuhkan kepada pikiran. $^{7}$ Demi keberhasilan pendidikan, lingkungan sekolah, lingkungan keluarga, dan lingkungan masyarakat hendaklah dibangun yang sinergis dan bersama-sama mendukung proses pendidikan dan pembelajaran di kelas. ${ }^{8}$ Adapun proses pembelajaran di kelas, yang paling berpengaruh terkondisinya budaya akademis maupun budaya internalisasi nilai-nilai adalah guru.

Dalam kajian sosiologi pendidikan dikupas bahwa seorang anak manusia dalam proses mempelajari norma, mengenal dua klasifikasi sosialisasi, yakni klasifikasi primer dan sekunder. Pada sosialisasi primer, menunjuk pada suatu proses seorang anak manusia mempelajari atau menerima pengetahuan, sikap, nilai, norma, perilaku esensial, agar mampu berpartsipasi aktif di masyarakat. Pada sosialisasi sekunder yang sering dikenal resosialisasi, merupakan proses mempelajari norma, nilai, sikap, dan perilaku baru agar sepadan dengan situasi baru yang mereka hadapi dalam kehidupan. ${ }^{9}$ Dalam kaitan ini, seorang siswa bisa dibentuk melalui proses pembelajaran, baik itu aspek pengetahuan, aspek keterampilan maupun aspek sikap dan perilaku.

Penelitian Deitje Adolfien Katuuk menyatakan bahwa, di dalam implementasi kurikulum, terutama kurikulum baru akan mengahadapi banyak masalah. Katuuk mengidentifikasi faktor-faktor dalam implementasi kurikulum, ${ }^{10}$ dalam Skema yang telah dimodifiksi sebagai berikut:

\footnotetext{
${ }^{7}$ Darmiyati Zuchdi, Pendidikan Karakter Konsep ...., h.17.

${ }^{8}$ Darmiyati Zuchdi, Pendidikan Karakter Konsep ...., h.25.

9Damsar,Pengantar Sosiologi Pendidikan. Jakarta: Kencana, 2011, h. 67.

10Deitje Adolfien Katuuk. Manajemen Implementasi Kurikulum: Strategi Penguatan Implementasi Kurikulum 2013. dalam Jurnal Ilmiah Pendidikan Cakrawala Pendidikan, XXXIII (1), 2014, h.17.
} 


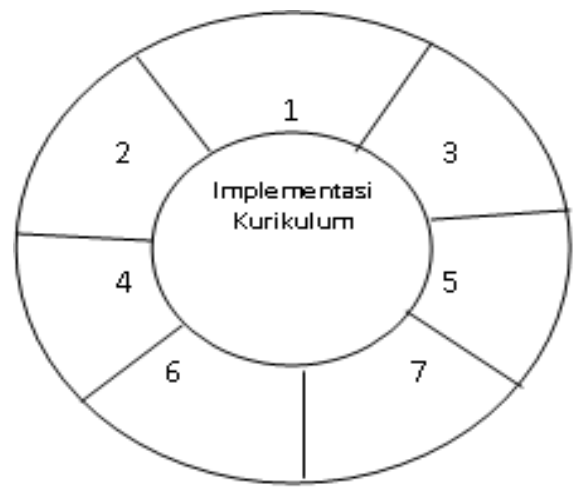

Faktor dalam Implementasi Kurikulim:

1. Kepala Sekolah

2. Guru

3. Dokumen Kurikulum

4. Perencanaan

5. Administrasi

6. Sarana Prasarana

7. Iklim Budaya Sekolah

Dalam kesimpulan penelitiannya disebutkan bahwa Guru dan Kepala Sekolah mempunyai peranan penting sebagai aktor utama dalam implementasi kurikulum. Demikian juga siswa, orang tua dan pengguna.

Dewan Pendidikan Kabupaten Sleman telah melakukan penelitian yang berjudul Kontribusi Media dan Kesadaran Beragama dalam Membangun Penampilan Karakter Diri Siswa SMA dan SMK di Lingkungan Keluarga, Sekolah, Masyarakat, dan di Lingkungan Diri Sendiri. Hasil penelitian ini diantaranya dinyatakan bahwa Keluarga menjadi lingkungan paling strategis dalam kontribusi dan penampilan karakter anak-anak kita, artinya keluarga memiliki otoritas besar terhadap control dan pengendalian karakter anak. ${ }^{11}$ Kajian sosiologi pendidikan akan memperkuat adanya proses bagaimana "pembelajaran dapat menembus dinding kelas", seperti yang diisyaratkan oleh kurikulum 2013.

\section{b. Proses Pembentukan Karakter dan Konsep Diri Keimanan dan Sosial dalam Indirect Teaching di Kelas}

Konsep diri menurut Allport, memberikan istilah khusus properium (self) yang terdiri dari proses-proses penting yang bersifat pribadi individu sebagai seorang yang unik mulai manusia bayi sampai adolensi melalui tujuh tingkat "diri", yang akhirnya pada tingkat "gambar diri" "diri sebagai pelaku sosial" (anak mulai sekolah), dan perjuangan properium (propriate

\footnotetext{
11Djohar, MS dkk., Kontribusi Media dan Kesadaran Beragama dalam Membangun Penampilan Karkter Diri Siswa SMA dan SMK di Lingkungan Keluarga, Sekolah, Masyarakat, dan Lingkungan Diri Sendiri. Yogyakarta: Dewan Pendidikan Kabupaten Sleman, 2012, h.78.
} 
Jurnal Pendidikan Agama Islam

striving). ${ }^{12}$ Rogers mengemukakan lima sifat “orang yang berfungsi sepenuhnya": (1) keterbukaan pada pengalaman; (2) kehidupan yang eksistensial/setiap pengalaman dirasa segar dan baru; (3) kepercayaan terhadap organisme sendiri; (4) berperasaan bebas; dan kreativitas/mampu menyesuaikan diri terhadap perubahan-perubahan. ${ }^{13}$ Konsep "diri" dari kedua ahli tersebut bahwa Allport menyebut manusia sebagai spesies yang "unik" ada proses-proses penting yang perlu diperhatikan diantaranya masa adolensi. Masa ini terjadi tarik menarik antar orang tua, teman dan sekolah, maka pencarian diri ini perlu disadari betul oleh para pendidik.

Tahap pengembangan diri (self) yang dikaitkan dengan sosialisasi dapat dikemukakan pemikiran dua ahli, yaitu George Herbert Mead (1972) dan Charles H. Cooley. Tokoh pertama mengkaitkan teori peran dengan sosialisasi melalui beberapa tahap. Tokoh kedua menekankan pada peran interaksi dalam proses sosialisasi yang membentuk konsep diri.Menurut Mead, pengembangan diri manusia berlangsung melalui beberapa tahap, play stage, game stage, dan genelized other. Menurut Mead pada tahap ini orang telah mempunyai diri. Jadi menurut Mead "diri seseorang" itu terbentuk melalui interaksi dengan orang lain.

Pandangan Cooley tentang konsep diri (self concept) seseorang berkembang juga melalui interaksinya dengan orang lain. "Diri" yang berkembang melalui interaksinya dengan orang lain oleh Cooley dinamakan looking-glass self. Analogi itu dalam pembentukan diri seseorang seperti kalau cermin memantulkan apa yang di depannya. ${ }^{14}$

Dalam hal "agen" sosialisasi, Fuller dan Jacobs (1973) mengidentifikasi ada empat agen sosialisasi, yakni keluarga, kelompok

\footnotetext{
12Yustinus, Semiun. Kesehatan mental 2. Yogyakarta: Kanisius, 2006, h. 36.

${ }^{13}$ Yustinus, Semiun. Kesehatan mental ...., h.54.

${ }^{14}$ Kamanto Sunarto. Pengantar Sosiologi, edisi ketiga. Jakarta : Lembaga Penerbit Fakultas Ekonomi, Universitas Indonesia, 2004: h.22-23.
} 
bermain, media, dan sistem pendidikan. Pada tahap sosialisasi keluarga peran utama adalah orang tua dan saudara kandung. Untuk bisa berinteraksi dengan significant others, seseorang belajar berkomunikasi secara verbal dan non verbal. Pada agen teman bermain, sebagian kemampuan baru didapat dan dipelajari oleh anak. Pada tahap inilah anak memasuki game stage mempelajari aturan yang mengatur peran orang yang kedudukannya sederajat.

Terkait dengan konsep diri religius, dengan mencermati fenomena keberagamaan secara teoritis, berikut dikemukakan salah satu konsep yang banyak dianut para ahli psikologi dan sosiologi.Bahwa unsur-unsur keberagamaan meliputi kepercayaan keagamaan (religious belief) atau aqidah sebagai dimensi ideologi; praktek keagamaan (religious practice) sebagai dimensi ritual. Dimensi penghayatan keberagamaan (religious feeling) sebagai dimensi pengalaman; pengetahuan keagamaan (religious knowledge) sebagai dimensi intelektual; dampak keagamaan (religious effects) sebagai dimensi konsekuensial dalam tampilan citra diri seseorang, dengan Iman menjadi penggeraknya. ${ }^{15}$

Dalam pandangan agama Islam, nilai Iman menduduki tempat yang lebih tinggi daripada Islam itu sendiri. Dalam Al-Qur'an disebutkan bahwa ada orang Islam tetapi belum beriman, karena iman belum masuk dalam hatinya; maksudnya iman seperti dikehendaki oleh Allah SWT. Firman Allah dalam Al Qur'an yang artinya: “Orang-orang Arab Badui itu berkata: 'Kami telah beriman'. Katakanlah (kepada mereka): 'Kamu belum beriman', tetapi katakanlah 'kami telah Islam', karena iman itu belum masuk ke dalam hatimu..."16Berdasar ayat itu, maka kedudukan iman itu sangat penting dan merupakan ruh penggerak dari dalam lubuk hati ke otak atau pikiran manusia dan otak yang menyuruh anggota badan untuk beraktivitas. Oleh

\footnotetext{
15Djamaluddin Ancok \& Fuad Nashori Suroso, Psikologi Islam,Yogyakarta: Pustaka Pelajar, 1985, h.76-77.

${ }^{16}$ QS. al- Hujurat [44]: 14.
} 
karena itu wajar kalau masih banyak orang Islam melakukan kemaksiatan, barangkali mereka baru 'Islam' tetapi belum beriman dalam hatinya.

Religiusitas perpektif Kristen (dalam pembelajaran di sekolah) dalam kupasan singkat ini diwakili oleh pandangan Romo Mangunwijaya mengupas dalam pembahasannya "dari pelajaran agama ke-pendidikan religiusitas" menyebut bahwa yang eksklusif agama dan yang inklusif adalah iman religiusitas. Dalam tawarannya, demi iman yang dipandang lebih penting daripada agama, maka "komunikasi iman" bukan pelajaran agama yang diperlukan di sekolah. Hal tersebut dapat dilihat dalam kaca mata dan bingkai Pancasilais dan pluralitas. Adapun pelajaran agama (eksklusif) menurut beliau menjadi tanggung jawab gereja, paroki atau masjid yang memang dan harus eksklusif. Lokasinya orang tua, keluarga inti/luas, paroki, lingkungan dan sekolah minggu. Jadi di sekolah dikemas dalam 'komunikasi Iman' dalam kerangka oekumenis lintas agama dan tidak dalam kerangka pelajaran agama Katolik (terselubung). Komunikasi atau interaksi iman sehingga anak-anak punya sikap dasar betul, hati nurani yang peka terhadap yang baik, yang adil, yang benar, yang suka menolong, dan senang membuat orang lain gembira. ${ }^{17}$

Dalam konteks di lapangan, sebagai contoh kegiatan pembelajaran di kelas SMA BOPKRI I pada mata pelajaran bahasa Inggris, siswa diberi tugas "faktor report", setelah guru memberikan tugas untuk pengamatan ke tempat-tempat lingkungan sekolah, untuk mendidik kemandirian, siswa di kelas dibagi (dua orang-dua orang) menuju ke tempat lingkungan yang telah ditentukan oleh guru. Para siswa kemudian menuju/mengamati di ruang guru, tempat parkir guru, tempat parkir siswa, ruang laboratorium, ruang perpustakaan, ruang tamu dan ruang aktivitas yang lain. Di sini siswa diberi penekanan pembiasaan (seperti yang peneliti amati), siswa bisa

\footnotetext{
17Mangunwijaya, Y.B.. “Novel Saya dan Lakon Wayang”. Dalam Sindhunata (Ed.). 2003. Menjadi Generasi Pasca-Indonesia: Kegelisahan Y.B. Mangunwijaya. Yogyakarta: Kanisius,1997, h. 109-119.
} 
"bekerja sama”, berlatih "jujur" untuk melapor apa adanya yang terjadi serta dibiasakan untuk "peka terhadap lingkungan". Tetapi menurut penuturan para guru, untuk membangun keimanan dengan cara mengkaitkan dengan K.I. 3 dan K.I. 4 agak sulit, ketika materi tidak terkait. Jadi guru lebih terikat dengan materi, ketika materi tidak menyangkut dimensi iman, mereka para guru menuturkan sulit mengkaitkan. Lain halnya dengan dimensi sosial, ketika siswa bekerja secara kelompok, siswa dapat membangun nilai-nilai kerja samanya, nilai kejujurannya, nilai kepekaan terhadap lingkungan dan lain-lain. Proses pembelajaran serupa seperti diuarai di atas (dalam arti guru tidak mengkaitkan materi dalam pencapaian Kompetensi Inti 1 dan Kompetensi Inti 2), juga terjadi pada proses pembelajaran Biologi di kedua kelas berbeda yang para penulis amati.

Sebenarnya guru bisa dan memang perlu lebih kreatif dan ada komitmen untuk terbangunnya K.I.1 dan K.I.2. Jadi walau dimensi keimanan tidak selalu terkait materi, tetapi siswa selalu bersinggungan dengan fenomena alam atau lingkungan. Jadi sebenarnya guru bisa mengajak siswa untuk merenung dan mengungkapkan, serta mengambil atau memaknai sendiri tentang apa yang diamati menjadi bernilai "keTuhanan" dan bernilai "sosial". Guru juga merasa kesulitan ketika menerapkan penilaian dalam sikap dan keterampilan dalam proses pembelajaran; terutama guru-guru yang tua. Menurut mereka hal tersebut karena beban mengajar dan tugas-tugas sudah terlalu berat.

Kegiatan pembelajaran di SMA Muhammadiyah I Yogyakarta dalam suatu pembelajaran Bahasa Sastra Indonesia, ketika Guru masuk, ruang bersih dan kursi siap untuk ditempati. Siswa berdo'a, dilanjutkan membaca Al-Qur'an dengan tertib, mereka membaca dengan penghayatan ada siswa dibelakang tidak membaca, hanya menyimak saja. Pukul 07.15 WIB Guru memanggil siswa untuk mengisi presensi. Materi pelajaran tentang 
Jurnal Pendidikan Agama Islam

perbedaan pantun-sya'ir-gurindam-puisi. Persamaannya tentunya samasama sebagai puisi lama. Siswa maju kedepan 4 siswa secara bergantian untuk menuliskan ciri-ciri dari pantun, syair, gurindam dan puisi. Siswa yang lain relatif agak pasif, bahkan 2 siswa dibelakang sangat pasif, dan tiduran dimeja, tanpa ditegur guru. Pembelajaran berlangsung sampai dengan 50 menit, belum tampak munculnya untuk menumbuhkan karakter sosial dan karakter keimanan. Guru masih terfokus pada analisis perbedaan puisi lama. Jadi dalam konteks ini, guru juga masih terikat kepada materi pelajaran. Sampai dengan pukul 08.10 WIB, masih terlihat ada 5 siswa yang tiduran (kepalanya diletakkan di meja), sementara guru terus menjelaskan dan menganalisis perbedaan puisi lama.

Dalam konteks tersebut, peneliti berpendapat, sebenarnya analisis dalam proses pembelajaran ini bisa ditugaskan secara kelompok untuk membangun kerjasama dan kepedulian sesama, serta pada kelompok juga bisa membuat atau memberi contoh tentang puisi lama. Kalau itu dilakukan, siswa juga bisa presentasi tentang hasil analisis mengemukakan perbedaan antara 4 jenis puisi lama, memberi contoh puisi lama yang sudah ada serta membuat contoh baru "ciptaan siswa-siswa sendiri", siswa lain bisa menanggapi-mengkritisi, dan guru maupun siswa lain bisa mengapresiasi karya siswa di kelas. Sampai dengan menjelang habis jam ke dua pembelajaran (pukul 08.25 WIB), ada 3 siswa yang tetap tiduran dimeja. Satu siswa tetap bertahan tiduran tanpa merespon penjelasan guru. Hal serupa dalam arti tidak munculnya pendidikan bagi dimensi Keimanan (K.I.1) dalam proses pembelajaran, terjadi juga pada pembelajaran bahasa Jawa, pembelajaran Seni rupa, maupun pembelajaran bahasa Inggris yang sempat teramati peneliti. Tentang dimensi Sosial (K.I.2), telah muncul dalam proses diskusi kelas, namun belum ada pemaknaan mengenai dimensi sosial ini. 
Jurnal Pendidikan Agama Islam

Karakter Iman sebenarnya bisa dibangun dari bervariasinya karyakarya orang-orang dari zaman ke zaman tentang puisi lama. Hal ini juga bisa dibangun, misalnya ada kerja kelompok, bisa ditugaskan kepada siswa langsung. Sehingga ketika siswa presentasi, siswa bisa menyampaikan temuannya (misalnya) tentang bagaimana dan apa karakter sosial yang dirasa terbangun dari kerja kelompok?. Bagaimana dan apa yang bisa diambil hikmah atau pelajaran dalam kehidupan dalam meningkatkan keimanan?. Jadi dalam pembelajaran tersebut, proses saintific yang muncul yakni proses mengamati dan menganalisis (tetapi yang banyak aktif gurunya); untuk proses menanya, mengasosiasi dan mempresentasikan, belum terlihat muncul dalam proses pembelajaran. Untuk menampilkan K.I.1 \& K.I.2, guru juga merasa terikat dan terkejar waktu dan materi, sehingga dikatakan masih menggunakan model campuran.

Di dalam Peraturan Menteri Pendidikan dan Kebudayaan RI Nomor 81A Tahun 2013 tentang implementasi kurikulum, bahwa dalam Kurikulum 2013, kompetensi inti (KI) dirumuskan sebagai berikut: (a) KI-1: kompetensi inti sikap spiritual, (b) KI-2: kompetensi inti sikap sosial, (c) KI3: kompetensi inti pengetahuan, (d) KI-4: kompetensi inti keterampilan. Perlu diingat, bahwa Kompetensi Dasar-Kompetensi Dasar (KD-KD), diorganisasikan ke dalam empat KI. KI-1 berkaitan dengan sikap diri terhadap Tuhan Yang Maha Esa. KI-2 berkaitan dengan karakter diri dan sikap sosial. KI-3 berisi KD tentang pengetahuan terhadap materi ajar, sedangkan KI-4 berisi KD tentang penyajian pengetahuan. KI-1, KI-2, dan KI-4 harus dikembangkan dan ditumbuhkan melalui proses pembelajaran setiap materi pokok yang tercantum dalam KI-3, untuk semua matapelajaran. KI-1 dan KI-2 tidak diajarkan langsung, tetapi indirect teaching pada setiap kegiatan.

Disebutkan juga bahwa KD-1 dan KD-2 dari KI-1 dan KI-2 tidak harus dikembangkan dalam indikator karena keduanya dicapai melalui 
proses pembelajaran yang tidak langsung (indirect teaching). Indikator dikembangkan hanya untuk KD-3 dan KD-4 yang dicapai melalui proses pembelajaran langsung. Adapun untuk KD pada KI-1 dan KI-2, ketuntasan seorang peserta didik dilakukan dengan memperhatikan aspek sikap pada KI-1 dan KI-2 untuk seluruh matapelajaran, yakni jika profil sikap peserta didik secara umum berada pada kategori baik (B) menurut standar yang ditetapkan satuan pendidikan yang bersangkutan. Berdasar cuplikan Permendiknas tersebut menunjukkan bahwa peluang pendidikan karakter sangat besar, karena adanya peluang pada Kompetensi Inti 1 dan Kompetensi Inti 2. Di sini akan dipertaruhkan kompetensi dan komitmen spiritrualitas guru serta komitmen kompetensi sosial guru. Komitmen dan kompetensi guru tersebut akan sangat berperan dalam pembentukan karakter konsep diri religiusitas sebagaimana diuraikan di atas.

Pandangan para guru di lapangan (di SMA Bopkri I), bahwa pendidikan karakter di kelas ditunjang dan dikuatkan oleh kultur yang telah terkondisi di sekolah, seperti pergaulan se hari-hari di sekolah. Karakter hormat menghormati ditanamkan melalui tegur sapa antara sesama teman baik yunior maupun senior, ketika siswa bertemu guru juga jabat tangan dan cium tangan. Gank siswa juga terkendali walau pernah muncul ketika sekolah dilempar batu oleh segerombolan siswa lain sekolah yang tidak dikenal, tetapi dipesan oleh guru “jangan melawan!” yang bertanggung jawab guru dan karyawan. Dalam hal penilaian, menurut penuturan waka kurikulum, penilaian objektif, psikomotorik secara administratif bisa berjalan. Penilaian afektif setiap saat berlangsung pada jam dikelas, tetapi terkendala dengan jumlah siswa dan guru biasanya berorientasi pada materi pelajaran. Menurut penuturan para guru, pelaksanaan KI.1 dan KI.2 dalam kurikulum 13, bisa berjalan, tetapi seperti dipaksakan. Dari sisi wawasan memang kebanyakan masih dipahami secara setengah-setengah, 
memang sudah ada pelatihan, tetapi dirasakan hanya pada saat pelatihan saja, setelah selesai pelatihan jarang yang digunakan.

Menurut para guru, dalam pelaksanaan serta evaluasinya memang sulit dilaksanakan secara ideal. Rencana pelaksanaan pembelajaraan (RPP) memang bisa dibuat, apalagi format sudah ada, mentor ada tetapi tetap saja dalam pelaksanaan banyak kendala, seperti bagaimana di lapangan terkait dengan penilaian, terutama penilaian sikap. Penilaian sikap walau sudah dibuat pada rubrik tetapi biasanya jamnya kurang, ditambah kendala heteroginitas para siswa yang daya tangkap terhadap materi berbeda-beda, untuk tidak mengatakan siswa kurang pandai. Contoh lain penilaian teman sejawat dalam KI. 1 dan KI. 2, walau sudah dirancang tetapi belum bisa dilaksanakan, kalau penilaian pengetahuan memang sudah biasa, jadi kendalanya "waktu", "materi" ; kecuali kalau siswa bagus semua, mungkin bisa. Hal senada juga ditunjukkan di SMA Muhammadiyah I, dari hasil wawancara dengan guru, dalam praktik pendidikan karakter, kadang siswa dipanggil, atau misal dilihat shalatnya bagus dan seterusnya. K.I. 1 dan KI.2, sangat tergantung kepada guru yang bersangkutan. Untuk menuju secara ideal memang dirasa masih ada kesulitan-kesulitan. Menurut yang ditangkap dan dilaksanakan guru (dalam pelatihan) yang tidak harus muluk-muluk. Dalam memunculkan K.I.1 dan K.I.2, guru punya cara yang berbeda-beda.

\section{d. Strategi Penguatan Karakter Keimanan dan Sosial/Lingkungan}

Proses pembentukan karakter diri Keimanan dan sosial, tidak selalu harus terjadi melalui kegiatan dikelas, tetapi juga melalui budaya sekolah. Dalam lingkup Kultur kita bisa melihat Kedisiplinan, Patriotisme, Kekeluargaan, dan Keramahan. Hasil penelitian di SMA Bopkri I menunjukkan bahwa kegiatan di lingkup kultur, mulai pukul $06.30 \mathrm{~s} / \mathrm{d}$ 06.55 WIB dibangun nilai-nilai keramahan dengan salam-senyum-sapa. Pukul 06.55 s/d 07.10 : Guru melakukan renungan, siswa juga melakukan 
renungan, pukul $07.10 \mathrm{~s} / \mathrm{d} 07.20$ dilanjut siswa melakukan berdo'a secara sakral dan massal dipimpin oleh salah satu siswa dari Paguyuban Anak Bosa (PAB), dilanjutkan menyanyikan lagu Indonesia Raya. Ketika berdo'a dan menyanyikan lagu Indonesia Raya, para siswa, guru, satpam serta tukang parkir dan lain-lain, berdiri tegap dan ikut berdo'a, termasuk siapapun yang ada, walau di ruang tamu atau yang ditempat parkir sekalipun. Hal ini yang tidak ditemukan di tempat lain, mereka (warga sekolah) sangat menghargai/menghormati/menghayati lagu kebangsaan Indonesia Raya. Setelah itu, dilanjut pengumuman secara sentral apabila ada, sebelum pembelajaran dimulai.

Dalam membangun kultur kedisiplinan di sekolah ini, terlihat ketika do'a dan menyanyikan lagu kebangsaan, karakter keramahan bisa dirasakan ketika masuk halaman, disambut satpam yang ramah; disambut resepsionis yang tertib dan ramah. Kultur yang dibangun di sekolah ini antara lain menjiwai patriotisme, membangun jiwa kebangsaan, bersih, sehat, kekeluargaan dan keramahtamahan. Penanaman kedisiplinan guru dibangun dengan sistem antara lain pagi guru piket sudah hadir sejak 6.30, menyambut kedatangan siswa dengan senyum-salam-sapa. Guru piket juga merekap kejadian-kejadian pada hari itu termasuk kedisiplinan guru mengajar, dan kemudian melaporkannya kepada Kepala Sekolah. Kepala Sekolah merekap dan menganalisa, kejadian dalam satu minggu, dan menentukan apa saja yang perlu ditindak lanjuti dalam pembinaan pada minggu berikutnya, yang dilaksanakan pada setiap hari Senin. Kegiatan agama, dilaksanakan dalam lingkup kultur, sejak pagi ada kegiatan renungan pagi, do'a secara sentral dan dipimpin oleh siswa. Pembelajaran Agama lebih pada Pelajaran Religiusitas, tidak mendoktrin, jadi lebih bernuansa humanism. Persentase siswa yang berjumlah $\pm 75 \%$, Kristen, \pm $12 \%$ Islam $\pm 8 \%$ serta Hindu, Budha $\pm 5 \%$. Penelitian ini memang tidak mendata secara pasti tentang persentase pemeluk agama di sekolah, karena 
arah dan tujuan penelitian memang tidak ke arah hal tersebut, tetapi lebih melihat bagaimana proses penanaman dimensi Iman dan Sosialnya.

Religiusitas yang diterapkan di SMA Bopkri I, misalnya topik "pergaulan bebas", bagaimana "dikaji" secara Islam (oleh siswa yang beragama Islam), bagaimana "dikaji" secara Kristen (oleh siswa yang beragama Kristen) dan bagaimana perspektif Katolik (oleh siswa yang beragama Katolik). Demikian juga yang terkait dengan misalnya "hari besar agama” guru memfasilitasi dialog. Bagaimana makna Idul Adha dalam Islam, bagaimana makna Natal dalam Katolik. Jadi religiusitas dalam pembelajaran agama di sekolah ini lebih pada memanivestasi dari ajaran itu sendiri. Dalam hal ini menurut peneliti memang ada positifnya, tetapi mengandung kelemahan-kelemahan. Kelemahannya antara lain, bahwa tanggapan atau penjelasan siswa akan sangat subyektif dan sebatas apa yang diketahui siswa. Padahal makna-makna agama itu bisa lebih luas dan lebih dalam dari pada yang terlihat dipermukaan dan daripada pandangan siswa itu sendiri. Seharusnya yang bicara secara final tentang makna-makna suatu kegiatan keagamaan adalah ahlinya, sehingga maknanya benar dan tidak menyesatkan.

Dari sejumlah 55 orang guru di SMA Bopkri I, yang Muslim ada \pm 5 orang, Katolik ada \pm 10 orang, selainnya yang dominan tentunya beragama Kristen (Kristen Protestan). Karyawan yang beragama Islam ada \pm 6 orang, dan Katolik \pm 3 orang. Menurut penuturan wakil Kepala Sekolah, guru atau karyawan yang Muslim ketika datang waktu shalat dhuhur, mereka shalat dhuhur di ruang BK atau di masjid. Mereka yang beragama Islam ini, ketika hari Jum'at juga bisa melaksanakan shalat Jum'at, karena pembelajaran berakhir pukul 11.35, tentang siswa muslim, shalat dhuhur atau shalat Jum'at, tentu tidak ada yang mengontrol, kecuali keluarganya atau orang tuanya. 
Strategi penguatan karakter religiusitas dan sosial di SMA Muhammadiyah I, terbangun secara konseptual (tertera dalam lieflet, sebagai sekolah kader Muhammadiyah dan Bangsa), serta dibangun dari waktu kewaktu dalam kegiatan keagamaan secara kultural. Sekolah kader ini memiliki visi "Menghasilkan tamatan berwawasan masa depan yang berakhlaqul karimah, unggul dalam IMTAQ dan IPTEK". Tujuan (yang berkaitan dengan pendidikan karakter Keimanan dan Sosial) sekolah ini antara lain Sekolah Muhammadiyah dengan kurikulum yang seimbang antara kurikulum umum dan Islam, kemuhammadiyahan dan bahasa arab. Pengembangan minat dan bakat peserta didik dengan 33 ekstra kurikuler dan muatan lokal. Target peserta didik kelas X khatam s.d. juz 10, kelas XI khatam s.d. juz 20 dan kelas XII khatam s.d. juz 30. Pelibatan siswa dalam kegiatan Social Worker, Mubaligh hijrah, Hisbul Waton dan Karawitan. Sekolah ini menyediakan asrama As-Sakinah bagi peserta didik yang berminat dengan visi "Mewujudkan kader Muhammadiyah yang kuat Iman, dan taqwanya, berakhlaq mulia, disiplin, visioner, cerdas dan berprestasi. Kegiatan santri meliputi pembinaan keagamaan seperti tadarus Al-Qur'an, talaqqi, qiyamullail, dan pendidikan akhlak muslim. Pelatihan kader kepemimpinan yang dikemas dalam seminar, soft skill, outbond dan lainlain. Kegiatan tersebut menunjukkan bahwa pembentukan karakter KeImanan dan sosial lebih dibangun melalui kegiatan yang memang sudah dikonsep dan dilaksanakan secara kultural.

\section{E. Simpulan}

Dari hasil pembahasan diatas dapat disimpulkan bahwa:

1. Pembentukan karakter diri Keimanan/spiritual pada kedua sekolah ini, sama-sama belum tampak muncul dalam konteks pembelajaran di kelas. Para guru rata-rata masih merasa terikat dengan materi pelajaran. Kompetensi Inti 1 (K.I.1) yang mestinya bisa ditarik dari K.I. 
3 dan K.I.4 (sesuai pedoman pelaksanaan kurikulum 2013), belum muncul dalam konteks pembelajaran. Dalam pembentukan karakter Sosial terdapat kesamaan pembentukannya juga, yakni seperti sikap sosial kerjasama, gotong-royong, tolong-menolong, melayani, dan lainlain, telah terbangun melalui kerja/diskusi kelompok. Tetapi dalam hal ini juga belum/tidak ada pemaknaan bagi siswa tentang karakter tersebut, yang sebenarnya hal tersebut bisa difasilitasi oleh guru.

2. Strategi penguatan implementasi kurikulum 2013 dalam membangun karakter Iman dan Sosial pada ke dua sekolah ini, dapat terlihat melalui kegiatan yang bersifat kultural atau budaya sekolah dalam titik tekan dan karakteristik yang berbeda. Karakter Iman terbangun melalui kegiatan yang terkait dengan kegiatan keagamaan, sedangkan karakter sosial seperti kedisiplinan, patriotisme, kekeluargaan, dan keramahan juga terbangun dalam kegiatan kultural sekolah. 


\section{DAFTAR PUSTAKA}

Conny R Semiawan.(2007).Catatan Kecil Tentang Penelitian dan Pengembangan Ilmu Pengetahuan, Jakarta: Prenada

Darmiyati Zuchdi. (2012). Pendidikan Karakter Konsep Dasar dan Implementasi di Perguruan Tinggi. Yogyakarta: UNY Press.

. (2013). Model Pendidikan Karakter, Terintegrasi dalam Pembelajaran dan Pengembangan Kultur Sekolah, Yogyakarta: Jl. Wonosari, Mantub No. 144 RT 15

Deitje Adolfien Katuuk. (2014). Manajemen Implementasi Kurikulum: Strategi Penguatan Implementasi Kurikulum 2013. dalam Jurnal Ilmiah Pendidikan Cakrawala Pendidikan, XXXIII (1), hlm.13-26.

Ditjen Dikdasmen Depdiknas. (2002). Memahami budaya sekolah.

Depdiknas. (2003). Undang-undang RI nomor 20, tahun 2003, tentang sistem pendidikan nasional.

Djohar, MS dkk. (2012). Kontribusi Media dan Kesadaran Beragama dalam Membangun Penampilan Karkter Diri Siswa SMA dan SMK di Lingkungan Keluarga, Sekolah, Masyarakat, dan Lingkungan Diri Sendiri. Yogyakarta: Dewan Pendidikan Kabupaten Sleman.

Djamaluddin Ancok \& Fuad Nashori Suroso, (1985) Psikologi Islam,Yogyakarta: Pustaka Pelajar.

Kamanto Sunarto. (2004). Pengantar Sosiologi, edisi ketiga. Jakarta: Lembaga Penerbit Fakultas Ekonomi, Universitas Indonesia.

Kemendikbud. (2013). Permendibud No. 65 Tahun 2013, Tentang Standar Proses Pendidikan Dasar dan Menengah. Jakarta

Mangunwijaya, Y.B. (1997). "Novel Saya dan Lakon Wayang". Dalam Sindhunata (Ed.). 2003. Menjadi Generasi Pasca-Indonesia: Kegelisahan Y.B. Mangunwijaya. Yogyakarta: Kanisius.

Sugiyono. (2006). Metode Penelitian Kualitatif, Bandung: PT. Rosda Karya. 
Jurnal Pendidikan Agama Islam 